Kapata Arkeologi, 12(2), 191-198

ISSN (cetak): 1858-4101

ISSN (elektronik): 2503-0876

http://kapata-arkeologi.kemdikbud.go.id

\title{
NILAI-NILAI SOSIAL DAN RELIGI DALAM TRADISI MEGALITIK DI SULAWESI SELATAN
}

\section{Social and Religi Values in Megalithic Tradition in South Sulawesi}

\author{
Hasanuddin \\ Balai Arkeologi Sulawesi Selatan - Indonesia \\ Jl. Pajjaiyyang No. 13 Sudiang, Makassar \\ udin.balar@gmail.com
}

Naskah diterima: 16/09/2016; direvisi: 21/11 - 15/12/2016; disetujui: 15/12/2016

Publikasi ejurnal: 30/12/2016

\begin{abstract}
South Sulawesi is a region which has a several culture and megalith tradition that spread in various locations. Of those various forms and kinds of that megalith monument, there are important values that can be reinvented for the society. The purpose is to determine the social dan religious value of megalithic culture in South Sulawesi. In order to recognize those values, a research with an ethnoarchaeological approach has been done through direct observations and surveys in the society which still have megalith tradition, and focused to identify its values and functions in society. This research found that this tradition was developed since the $2^{\text {nd }} A D$ until the $10^{\text {th }}$ to $13^{\text {th }} A D$. During that period, the settlement system was composed of small communities that occupying highland and lowland. That small community was called wanua which spread across South Sulawesi peninsula. At the present time, that megalith tradition is still found in Torajan community, and in several ritual practices among communities in Enrekang and Soppeng regency, South Sulawesi. Generally, that megalith tradition is endorsing several values such like cooperation and spiritual.
\end{abstract}

Keywords: tradition, ritual, settlements

\begin{abstract}
Abstrak
Sulawesi Selatan merupakan suatu daerah yang memiliki beberapa bentuk budaya dan tradisi megalitik (kebudayaan batu besar) yang tersebar di berbagai wilayah. Dari berbagai bentuk dan jenis megalitik itu tentunya memiliki nilai-nilai yang dapat diterapkan dalam masyarakat. Tujuannya adalah untuk mengetahui nilai sosial dan religi dari kebudayaan megalitik di Sulawesi selatan. Dalam pencapaiannya digunakan pendekatan etnoarkeologi dengan cara melakukan survei di beberapa daerah di Sulawesi Selatan yang memiliki peninggalan megalitik. Selanjutnya dilakukan wawancara dan pengamatan langsung di masyarakat yang masih menggunakan kebudayaan megalitik untuk mengetahui fungsi dalam masyarakat. Penelitian selama ini menunjukkan bahwa kebudayaan ini berawal sekitar abad ke-2 Masehi dan terus berlanjut pada abad ke-10 hingga abad ke-13 Masehi. Sistem permukiman pada masa itu merupakan kelompok-kelompok komunitas yang menempati wilayah ketinggian dan dataran rendah. Pada awal terbentuknya populasi disebabkan adanya berbagai daerah otonom kecil yang disebut wanuwa yang terdapat di beberapa daerah di seluruh semenanjung Sulawesi Selatan. Budaya ini masih berkesinambungan hingga sekarang pada masyarakat Toraja, atau dalam praktek ritual seperti di Enrekang dan Soppeng, Sulawesi Selatan. Pada umumnya kebudayaan megalitik mengandung nilai-nilai kerjasama dan gotong royong serta religi yang menonjol.
\end{abstract}

Kata kunci: tradisi, ritual, permukiman

\section{PENDAHULUAN}

Kebudayaan materi (material culture) yang sering disebut dengan artefak merupakan suatu produk manusia masa lampau yang mempunyai makna dan nilai, karena pernah "hidup" di tengah masyarakat. Didalamnya tergambar berbagai sistem seperti sistem sosial dan religi yang harus diungkapkan. Dengan 
kajian yang mendalam terhadap kebudayaan materi, maka nilai-nilai yang melekat harus diungkapkan. Salah satu nilai yang melekat adalah nilai-nilai sosial yang melatarbelakangi terwujudnya kebudayaan tersebut.

Dalam pengkerangkaan prasejarah Indonesia (Soejono, 1984; Truman et al, 2012) telah membagi berbagai bentuk kebudayaan materi kedalam fase-fase kehidupan manusia. Dalam hal tersebut, kebudayaan megalitik dipandang lahir sebagai suatu akumulasi cara berfikir manusia untuk mewujudkan berbagai kepentingannya, seperti religi dan sosial. Sistem sosial dalam kebudayaan atau tradisi megalitik dapat dilihat pada fungsi dan tata cara dalam melaksanakan aktivitas yang berkaitan dengan kebudayaan tersebut. Dalam hal ini sistem yang dimaksudkan adalah kesatuan dari struktur yang mempunyai fungsi berbeda, namun satu sama lain saling memiliki ketergantungan dan bekerja ke arah tujuan yang sama. Masyarakat yang mememiliki suatu sistem yang kompleks apabila bagian-bagian didalam masyarakat saling berkaitan dan bekerja bersama-sama guna menjaga stabilitas.

Kebudayaan materi itu merupakan produk dari kegiatan sosial. Kajian kebudayaan materi sebagai hasil produk manusia masa lampau, berarti secara langsung menghidupkan kembali aspek sosial dari manusia yang meninggalkan kebudayaan materi tersebut. Aspek sosial menyangkut interaksi antarmanusia mengenai pemberdayaan dan kekuasaan,serta watak dari besaran organisasi manusia. Aspek tersebut sangat sulit diamati secara arkeologis, sehingga dibutuhkan kajian kebudayaan yang masih hidup dan memiliki hubungan bentuk dan fungsional. Oleh karena arkeologi bertumpu pada benda materi, maka ungkapan informasi yang harus diperoleh berkisar pada bentuk dan aspek teknologi, ekonomi, kehidupan sosial, dan hubungan dengan variabel lingkungan. Analisis yang menyeluruh mengenai unsur-unsur yang dimiliki suatu artefak merupakan upaya untuk mengetahui berbagai aspek dibalik keberadaannya, seperti proses penciptaannya, budaya yang menciptakan dan bagaimana benda itu tercipta. Hasil kajian terhadap artefak seperti itu kemudian dilakukan suatu rekonstruksi tentang bagaimana benda itu beroperasi dalam sistem budaya yang terorganisir (periksa Rouse, 1972: 95).
Kebudayaan dan tradisi megalitik tersebar secara merata di Sulawesi Selatan. Berbagai jenis dan bentuk peninggalannya mencerminkan perkembangan inovasi dan rekayasa teknologi. Pada masa protosejarah atau masa berkembangnya tradisi megalitik, wilayah Sulawesi Selatan juga memiliki sejumlah situs yang merupakan mata rantai dari budaya sebelumnya. Bahkan budaya ini masih berkesinambungan hingga sekarang pada masyarakat Toraja. Kebudayaan megalitik oleh kalangan ahli diposisikan sebagai hasil budaya yang diperkenalkan oleh kelompok migran penutur bahasa Austronesia yang masuk pertama kali ke Sulawesi Selatan pada kisaran waktu 4000 BP (Simanjuntak, 2008). Hasil pertanggalan radiokarbon tentang kebudayaan megalitik yang telah dilakukan oleh beberapa ahli selama ini menunjukkan umur yang paling tua diperoleh di Lembah Besoa (Sulawesi Tengah) yaitu 2,460 $\pm 120 \mathrm{BP}$ (cal. $831 \mathrm{SM}-$ 232 SM) (Yuniawati, 2010: 189) sedangkan di situs megalitik Tatelu (Sulawesi Tengah) terdapat tempat penguburan dengan pertanggalan $850 \pm 80 \mathrm{BP}$ dan $2,070 \pm 140 \mathrm{BP}$ (Yuniawati, 2006). Demikian pula penelitian tentang potensi budaya megalitik di Lembah Rampi, Sulawesi Selatan oleh Yuniawati (2014) telah menemukan permukiman megalitik dengan masa okupasi sekitar abad ke-2 - 3 Masehi.dengan jenis peninggalan seperti arca menhir, lumpang dan dolmen. Salah satu kajian unsur kebudayaan megalitik dalam bentuk keranda mayat (Toraja: erong) telah dilakukan oleh Akin Duli (2012) dengan pentarikhan menunjukkan masa perkembangan yang bermula di Toraja yaitu $1130 \pm 50 \mathrm{BP}(800 \mathrm{M})$, Enrekang antara $790 \pm 50 \mathrm{BP}(1200 \mathrm{M})$ hingga $570 \pm 40 \mathrm{BP}(1500 \mathrm{M})$, dan di Mamasa Sulawesi Barat antara 730 \pm 50 BP (Duli, 2012).

Apa yang telah diutarakan sebelumnya memberi gambaran mengenai berbagai sistem yang pernah berlangsung, seperti sistem sosial termasuk kekuasaan (kepemimpinan) dan religi. Pertanyaannya adalah (a) bagaimana nilai-nilai sosial yang terwujud dalam berbagai bentuk monumen megalitik di Sulawesi Selatan? dan (b) bagaimana sistem religi yang dianut masyarakat bercorak megalitik di Sulawesi Selatan? Sehubungan dengan itu, tulisan ini bertujuan mengkaji kontribusi nilai-nilai kebudayaan pada pemahaman edukasi kultural kepada masyarakat. Selain itu juga untuk 
mengetahui nilai sosial dan religi dari kebudayaan megalitik di Sulawesi selatan.

\section{METODE}

Untuk mencapai pemahaman yang maksimal dalam mengkaji tradisi megalitik berkaitan dengan sistem sosial maupun religi, digunakan alur pemikiran induktif dengan mengamati bentuk maupun jenis kebudayaan materi di wilayah Soppeng, Bulukumba, dan Tana Toraja. Tahap pengolahan data dan analisis dilakukan terhadap seluruh potensi data arkeologis yang ditemukan. Selanjutnya dilakukan pengkajian dengan pendekatan etnoarkeologi untuk menjelaskan fungsi dari masing-masing bentuk yang sesuai pokok kajian ini. Hasil kajian ini selanjutnya lebih menekankan nilai-nilai yang dikandung dari bentuk maupun jenisnya secara kontekstual.

\section{HASIL DAN PEMBAHASAN}

\section{Nilai Sosial dalam Struktur Batu Temu Gelang}

Berbagai bentuk dan jenis megalitik di Sulawesi Selatan merupakan bentuk inovasi yang menarik untuk diperhatikan dalam bidang sosial. Sistem tersebut dapat ditemukan pola yang ditunjukkan oleh penataan megalitik Sulawesi Selatan. Pola penempatan susunan batu melingkar yang disebut temu gelang (stone enclosure) seperti terlihat di Bantaeng, Bulukumba, Selayar dan Soppeng mengingatkan pada konsep kepercayaan masyarakat dalam menandai titik pusat dari segalanya. Dengan demikian, tidak mengherankan jika temu gelang senantiasa dihubungkan dengan pusat kampung setiap daerah (Bahasa Makassar: pocci butta). Pocci Butta (Bugis: Possi Tana) adalah titik pusat kekuatan sekaligus titik kelemahan suatu daerah atau wanuwa.

Pembagian ruang-ruang dalam permukiman masyarakat menjadi formula yang berisi tentang suatu pengharapan kepada terbinanya kehidupan yang aman dan sejahtera. Manusia selalu mencari dunia eksistensinya melalui "dunia simbol" melalui suatu perlambangan bentuk sebagai replika dari wujud sesuatu. Namun demikian, terkadang manusia tidak mampu menunjukkan eksistensinya secara abadi, sehingga hal itu dibangunnya melalui dunia ritus (periksa Pelras, 2006: 51).
Situs megalitik yang memiliki batu temu gelang yang dijadikan simbol Pocci Butta atau Possi Tana (pusat bumi atau pusat kampung) ditemukan pada tiga wilayah di Sulawesi Selatan merupakan susunan batu melingkar yang di tengahnya diletakkan satu altar batu. Kehadirannya merupakan implementasi sistem religi yang senantiasa sangat disakralkan oleh masyarakat. Bahkan masyarakat meyakini sebagai pusat kekuatan magis di daerah tersebut. Lokasi tersebut digunakan untuk upacara-upacara ritual yang berkaitan dengan pertanian, yaitu memohon kepada leluhur agar hasil panen untuk satu musim tanam berjalan menghasilkan padi yang lebih bagus. Di tempat ini pula sering dilakukan upacara dengan memotong ayam, kambing, kerbau/sapi.

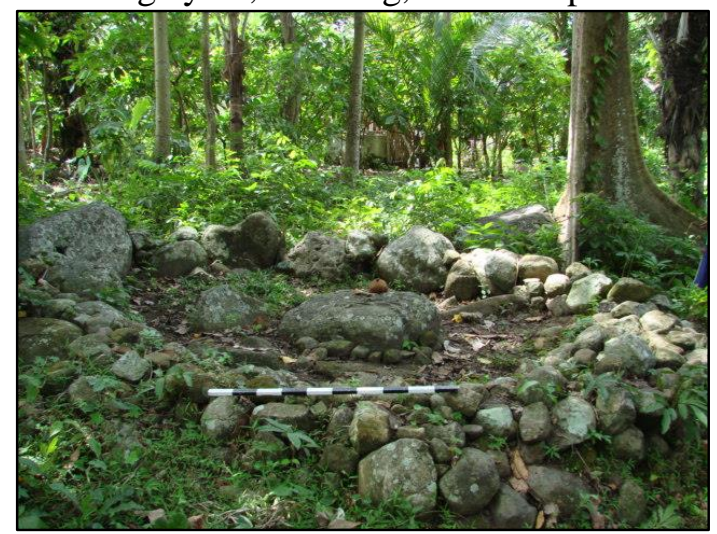

Gambar 1. Batu temu gelang (stone enclosure) yang oleh masyarakat disebut pocci butta (pusat bumi) berbentuk melingkar disusun dari batuan andesit ditemukan di Bantaeng (Sumber: Hasanuddin, 2015)

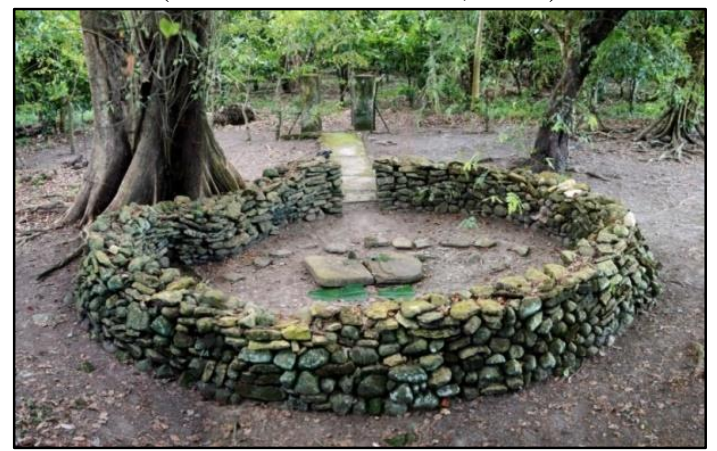

Gambar 2. Batu temu gelang (stone enclosure) yang disebut Possi Butta (pusat bumi) di Kajang, Bulukumba yang kini digunakan sebagai tempat pelantikan ketua adat (Sumber: Hasanuddin,(2015)

\section{Nilai Sosial dalam Bentuk Relasi Kuasa}

Berbagi bentuk megalitik seperti temu gelang, menhir dan batu alam yang dijadikan 
sebagai sarana pemujaan masih dilakukan oleh sebagian masyarakat Bugis Makassar dan sebagian besar masyarakat Toraja hingga kini. Upacara yang dilakukan oleh sebagian masyarakat Bugis Makassar erat kaitannya dengan upacara syukuran atas keberhasilannya dalam usaha pertanian. Menurut David Bulbeck, orang-orang Bugis Makassar memiliki ciri-ciri ekspresi fenotip (phenotypically) yang disebarkan oleh populasi manusia di Asia Tenggara kepulauan. Pada dasarnya ciri-ciri antropomorfik yang ditunjukkan memiliki ciri populasi manusia di Kepulauan Indonesia Malaysia. Glinka (1981:105 yang dikutip oleh Bulbeck) menyebutkan bahwa orang-orang Bugis Makassar memiliki ciri fisik yang sama dengan populasi penduduk pribumi Taiwan, Philipina, Malaysia bagian Barat, dan pesisir Borneo (Bulbeck, 2004: 224).

Salah satu penyebab terjadinya penyebaran populasi penduduk adalah perubahan konstelasi politik. Pada awal terbentuknya populasi disebabkan adanya berbagai daerah otonom kecil yang disebut wanuwa yang terdapat di beberapa daerah di seluruh semenanjung Sulawesi Selatan. Memang pada awalnya wanuwa-wanuwa hanya dipimpin oleh para matoa (para tetua) namun dengan hadirnya Tomanurung, peran para matoa kemudian digantikan oleh raja yang berarti pula membawahi beberapa matoa. Dalam menjalankan pemerintahannya, seorang raja atau pemimpin memiliki kewenangan dan sistem pemerintahan yang diterapkan bersifat mutlak. Tidak disebutkan adanya sistem perwakilan rakyat, namun fungsi itu dijalankan oleh para Matoa karena para Matoa merupakan perwakilan dari seluruh rakyat. (Pelras, 2006: 125-126).

Berdasarkan sumber lontara, disebutkan bahwa beberapa daerah seperti Tinco dan Sewo (Soppeng), dan Onto dan Gantarang Keke (Bantaeng) merupakan pusat pemerintahan kerajaan masa pra-Islam. Keterangan tersebut memastikan bahwa dahulu sebuah permukiman yang telah memiliki pemimpin, pemerintahan, rakyat, dan wilayah kekuasaan. Apa yang dikemukakan dalam isi lontara tersebut, juga dibuktikan dengan budaya materi berupa temuan-temuan budaya materi (peninggalan arkeologi). Di beberapa daerah di Sulawesi Selatan, terdapat bongkahan batu besar yang sering dihubungkan dengan simbol atau mitos kedatangan orang pertama (tomanurung) sebagai "calon raja" dan sekaligus awal terbentuknya kerajaan di daerah tersebut seperti di Bantaeng, Soppeng, Sidenreng Rappang, Sinjai dan Bulukumba). Pelantikan raja-raja Bugis dan Makassar pada umumnya dilakukan di atas batu besar, sehingga para raja sering diberi gelar "Sang Pemijak Batu" atau pattuppu batu (Pelras, 2006: 32).

Bentuk peninggalan budaya megalitik yang besar dan bervariasi serta jumlah yang banyak, menunjukkan suatu corak masyarakat yang sudah teratur dengan sifat gotong royong yang tinggi. Hal demikian terlihat dari bentukbentuk megalitik yang didirikan, mempunyai ukuran besar yang tidak mungkin dilakukan oleh satu orang. Pelaksanaannya membutuhkan keterlibatan orang dalam jumlah yang banyak hingga ratusan orang. Dengan demikian, sistem gotong royong yang terkait dengan kebudayaan megalitik di Sulawesi Selatan diperoleh dari studi etnografi terutama pendirian tugu batu (dalam arkeologi disebut menhir dan dalam bahasa Toraja disebut simbuang).

Pendirian simbuang di Toraja merupakan legitimasi sosial dan sekaligus memiliki pesan moral. Simbuang sebagai simbol status dan kehadirannya disebabkan oleh sifat kebersamaan dan gotong royong masyarakat. Pelaksanaannya digerakkan oleh relasi kuasa, dimana seorang pemimpin atau orang yang memiliki kemampuan ekonomi dapat melaksanakan hal itu karena melibatkan orang dalam jumlah yang banyak. Keberadaan simbuang (menhir) di Toraja erat kaitannya dengan upacara kematian. Kegiatan yang lebih awal dilakukan dalam rangkaian upacara kematian yaitu pengadaan batu-batu menhir untuk ditancapkan di tempat upacara (rante). Teknik sederhana untuk pengangkutan simbuang, yaitu menggunakan beberapa batang pohon enau sebagai landasan dan diletakkan secara bergantian. Selanjutnya ditarik dengan menggunakan akar kayu oleh puluhan hingga ratusan orang dan dikoordinir oleh ketua adat. Apabila melalui daerah ketinggian, maka pohon kayu yang dijadikan landasan dipasang dengan posisi melintang. Namun jika melewati daerah lembah maka landasannya dipasang membujur. Sebelum bahan menhir diangkut terlebih dahulu dilakukan upacara dengan mengurbankan satu ekor babi (Hasanuddin, 2003: 56). 
Di bawah simbuang yang didirikan di setiap rante (lokasi upacara kematian) di Toraja diletakkan pula manik-manik kuning dan sepotong besi dengan harapan agar para keturunanannya tetap mengenang leluhurnya. Warna keemasan dari manik-manik menyimbolkan kebangsawanan dan besi adalah kekuatan dari orang yang meninggal. Demikian pula halnya dengan sesajian babi pada saat batu ditarik, mencerminkan kepercayaan bahwa fungsi dan tujuan seorang bangsawan dapat terpenuhi yaitu untuk keselamatan dan pengukuhan status sosial (Buijs, 2009: 136137). Demikian pula halnya dengan pembuatan liang $p a^{\prime}$ (lubang yang dipahat di batu untuk tempat penguburan di Toraja) menunjukkan adanya kekuasaan dalam pelaksanaannya. Kemampuan ekonomi dan pengaruh dalam masyarakat karena harus memberi upah kepada pekerja. Sebelum memulai memahat, terlebih dahulu diupacarakan dengan kurban hewan babi 10 ekor dan terkadang juga dengan ayam.

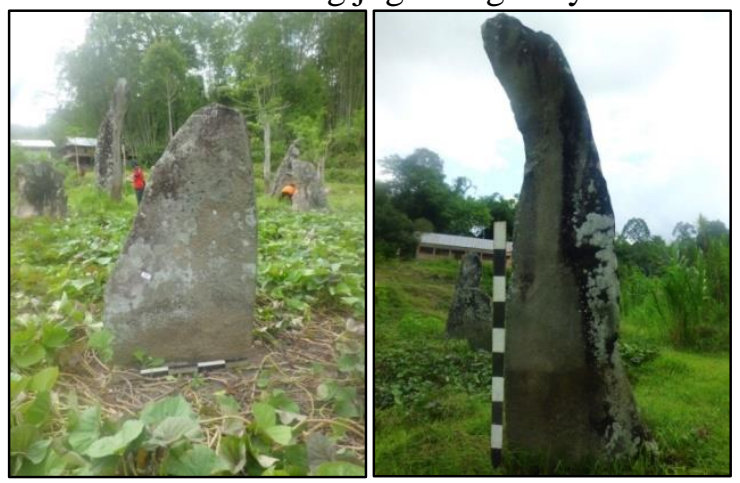

Gambar 3. Dua bentuk simbuang (menhir) yang terdapat di Toraja bagian Utara

(Sumber: Hasanuddin, 2015)

Perbedaan ukuran simbuang di Toraja, disebabkan oleh beberapa faktor, yaitu pertama, faktor kemampuan ekonomi, untuk membuat simbuang dengan ukuran besar sangat dibutuhkan banyak pengorbanan secara ekonomi; kedua, faktor pengaruh dalam masyarakat, semakin kuat pengaruhnya maka semakin banyak orang yang menyumbangkan tenaga dan materi untuk mendirikan simbuang yang lebih besar; ketiga, faktor waktu, pendirian simbuang tidak boleh dilepaskan penggunaan waktu dan orang-orang yang terlibat di dalam pelaksanaan itu harus dijamin makan dan keluarganya.

Penjelasan mengenai upacara tarik batu (stone-dragging) di Toraja seperti telah diuraikan di atas, menunjukkan bahwa kegiatan tersebut dilaksanakan secara terorganisir yang membutuhkan biaya dan tenaga cukup banyak. Pendirian simbuang di Toraja merupakan simbol status sosial dan legitimasi kekuasaan bagi anak dan cucu yang ditinggalkannya, sebagai media untuk mempererat tali persaudaraan, media komunikasi antara pemimpin dengan rakyatnya, dan sebagai simbol kerjasama dalam bentuk gotong-royong (Duli, 2012: 415-418).

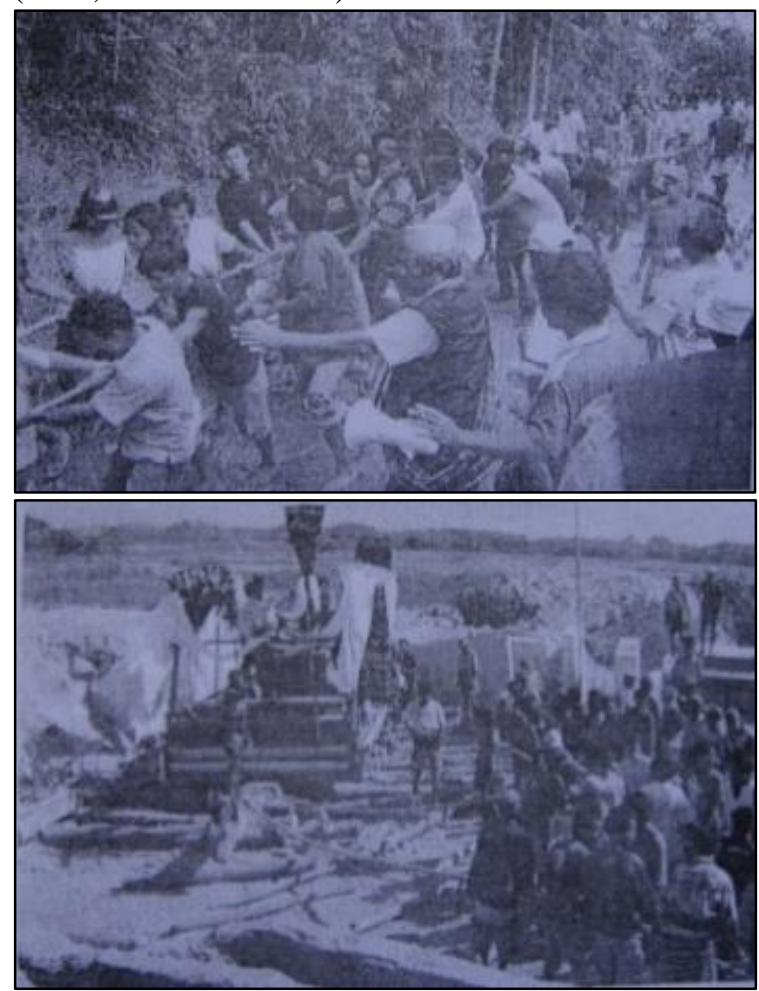

Gambar 4. Upacara penarikan batu (menhir) di Toraja (Sulawesi Selatan) dan di Sumba Barat (Sumber: Handini, 2008:445)

Pemindahan bahan dengan menggunakan landasan kayu seperti tersebut di atas juga merupakan teknik yang digunakan di daerah lain Indonesia seperti Nias (Hasanuddin, 2000) dan Sumba Barat (Handini, 2008). Di Sumba Barat, sebuah kubur batu dengan berat 12 ton ditarik oleh seribu orang dalam waktu tujuh jam, dengan jarak tempuh $\pm 2,2$ kilometer. Di Nias, Pelaksanaan pemindahan batu menhir dilaksanakan dalam rangkaian upacara kematian kepala suku. Batu ditarik dengan melibatkan 525 orang untuk mengangkut batu besar yang beratnya berkisar $8-10$ ton dari tempat pengambilannya ke desa tujuan dan berlangsung selama tiga hari hingga seminggu. 
Di luar Indonesia teknik sederhana seperti itu juga pernah dipraktekkan di Bougon, Prancis Barat tahun 1979. Dalam prakteknya digunakan tiga potongan kayu besar, masing-masing digerakkan oleh tenaga sebanyak 20 orang dan mampu memindahkan batu seberat 32 ton (Renfrew dan Bahn, 1991: 275).

Pendirian monumen megalit seperti di atas juga dipraktekkan oleh masyarakat di Dataran Tinggi Kelabit, Sarawak Malaysia. Dalam pelaksanaannya membutuhkan tenaga kerja manusia yang terorganisir dan saling bekerjasama. Megalit didirikan oleh orangorang, baik dari dalam kampung itu sendiri atau dari kampung terdekat di sekitar Kelabit. Dalam acara tersebut turut dilaksanakan Irau (pesta) dan peserta dari irau diharapkan dapat membantu pendirian megalit tersebut. Masyarakat yang bermukim di Kelabit pada zaman dahulu menganut sistem kelas secara hierarki (Rousseau, 1990), dan hanya bangsawan terkaya yang mampu melakukan irau karena mampu membayar tenaga orang yang membantu pendirian batu megalit. Bangsawan Kelabit memamerkan kekayaan mereka sepanjang irau (pesta) tersebut, di mana mereka melakukan irau untuk mempertahankan status sosialnya (Harrisson, 1958: 697). Puncak dari upacara irau adalah pesta makan besar kemungkinan dalam jumlah 500 orang yang berlangsung selama 4-5 hari. Semua peserta dalam irau berbaris dalam satu baris serta memindahkan batu-batu dari seorang ke yang lain dari sungai ke lokasi pendiriannya (Hitchner, 2009: 14-15)

\section{Sistem Religi}

Secara umum kebudayaan megalitik di Asia Tenggara menunjukkan bahwa kawasan ini mempunyai berbagai bentuk dan jenis yang digunakan untuk pemujaan, lambang kekuasaan, dan pertanian yang berkembang. Di Asia Tenggara, situs-situs megalitik berfungsi sebagai simbol kekuasaan, simbol para pemimpin, serta untuk penguburan. Pada masa perkembangan megalit di Asia Tenggara, praktek ritual masih dilakukan dan juga berkaitan dengan aktivitas pertanian seperti di Indonesia, Malaysia, Thailand dan Filipina (Hasanuddin, 2015).

Dalam konteks Asia Tenggara yang terdiri daripada daratan dan kepulauan, kebudayaan megalitik merupakan tinggalan arkeologi yang paling menonjol pada awal Masehi dan menembus waktu hingga zaman sejarah. Pada masa itu, manusia sudah mencapai kemajuan yang signifikan tentang penguasaan teknologi, struktur sosial, dan upacara religi. Penggunaan teknologi dalam menciptakan kebudayaan megalitik memberikan pemahaman mengenai berbagai aspek kehidupan masa lampau, termasuk mental template (konsep yang ada dalam fikiran si pembuat benda) dan pengetahuan dasar tentang batuan yang dapat dijadikan bahan untuk tujuan religi dan sosial. Manusia telah menciptakan bentuk budaya yang digunakan untuk tujuan tersebut dengan menerapkan unsur-unsur yang indah seperti meletakkan hiasan pada monumen. Demikian juga dengan upacara-upacara yang berkaitan dengan pendirian megalit yang senantiasa membutuhkan kerjasama dan gotong royong dengan jumlah orang yang banyak. Dalam pelaksanaan upacara yang berkaitan dengan pendirian megalit terdapat kesamaan dengan upacara Aluk Todolo di Toraja dan upacara owasa di Nias (Indonesia), upacara irau di Sarawak (Malaysia) dan di Lawa (Thailand). Demikian pula dengan praktek penanaman padi sawah merupakan sebagian dari kompleks megalitik, sama dengan yang terdapat di daerah Sumatera dan Sulawesi, di mana kebudayaan megalitik berpusat di dataran tinggi seperti di Indonesia (Pasemah, Toba, Kerinci, Poso, Kalimantan, dan di Sulawesi Selatan), Malaysia (Sabah - Sarawak), dan Laos di Provinsi Tak (Hasanuddin, 2015).

Pendirian simbuang (menhir) di Toraja jika dihubungkan dengan antropologi budaya, mencerminkan kehidupan yang bersifat potlatch, yaitu suatu kebiasaan yang memberi sebanyak mungkin. Kenyataan menunjukkan bahwa memberi lebih utama daripada menerima yang juga diartikan bahwa pihak pemberi lebih tinggi kedudukannya daripada penerima (Mauss, 1992: 3 - 6). Sebuah gambaran akan hal yang hampir sama yaitu tentang orangorang Tlingit dan Haida yang tinggal di pulaupulau dan pegunungan di Amerika Barat Laut yang biasanya mengadakan pesta makan secara besar-besaran. Kelompok suku bangsa yang berdiam di daerah tersebut menempatkan dirinya masing-masing secara hirarki. Kegiatan itu terwujud dalam pelaksanaan upacara pernikahan, inisiasi, upacara kultus dewa, 
totem, dan nenek moyang (Mauss, 1992: 5). Demikian juga dengan masyarakat Toraja yang melaksanakan upacara kematian secara besarbesaran bermuara pada pengukuhan status dan legitimasi sosial. Menurut kepercayaan masyarakat yaitu membiayai pesta secara besarbesaran turut meningkatkan martabat dan menjamin keselamatan lelehur yang diupacarakan. Meskipun dalam upacara kematian tampaknya mengandung sifat glamor (karena ada pengurbanan hewan dalam jumlah yang banyak), namun pengurbanan itu lebih dipandang sebagai persembahan dalam suasana upacara keagamaan dan bukan dalam nuansa pesta (Hasanuddin, 2003). Pemberian persembahan menyiratkan arti yang sangat mendasar, yaitu sebagai lambang untuk mengukuhkan hubungan antara si pemberi dan si penerima (Koentjaraningrat, 1985: 42). Persembahan itu harus dihayati sebagai kontribusi sosial dalam rumpun keluarga dan adat.

\section{KESIMPULAN}

Sulawesi Selatan merupakan suatu daerah yang memiliki beberapa bentuk budaya megalitik dan tersebar di berbagai wilayah. Baik bentuk maupun korelasinya dengan sumber daya alam serta berbagai nilai-nilai leluhur adalah data yang sangat mendasar untuk mengetahui berbagai bentuk aktivitas manusia masa lampau. Kebudayaan megalitik dengan berbagai corak dan nilai-niali yang terkandung di dalamnya merupakan gambaran betapa kayanya peninggalan arkeologis di Sulawesi Selatan yang dapat dijadikan dasar dari bentukbentuk awal peradaban manusia sekitar awal Masehi. Kehadiran kebudayaan megalitik memberi corak kehidupan tersendiri yang mengetengahkan nilai atau falsafah masyarakat masa lampau yang diaktualisasikan melalui penataan budaya megalitik, yang terdiri atas pemikiran penentuan pusat wilayah suatu daerah, adanya relasi kuasa dalam pendirian monumen megalitik, dan corak masyarakat agraris.

Situs-situs megalitik Sulawesi Selatan pernah menjadi tempat permukiman suatu komunitas yang memiliki kemampuan mengadaptasi lingkungannya. Komunitas ini pada awalnya mendiami puncak dan lereng bukit, demi menjaga keamanan dari ancaman bahaya binatang buas atau bahaya banjir.
Kemudian dengan semakin kurangnya ancaman bahaya dan semakin berkembangnya jumlah anggota komunitas, disamping tersedianya lahan yang lebih datar baik untuk cocok tanam maupun untuk tempat tinggal, di undak-undak (teras-teras) bekas endapan sungai, maka permukiman menyebar ke bagian kaki bukit dan akhirnya sampai ke undak-undak sungai dan dataran yang memiliki kemudahan aksesibilitas. Komunitas itu mulanya memiliki pengetahuan teknologi sangat minim dan sederhana, lalu berkembang menjadi komunittas yang berpengetahuan teknologi yang lebih maju untuk ukuran saat itu, baik dalam bercocok tanam ataupun mata pencaharian lain, maupun dalam membuat perlengkapan kehidupan mereka.

$$
\text { Kebudayaan megalitik yang }
$$

menghasilkan berbagai bentuk budaya materi yang pada umumnya terbuat dari batu, memberi pengetahuan yang tinggi kepada kita mengenai berbagai bentuk aktivitas masa lalu. Sejumlah budaya materi yang tercipta menyiratkan aktivitas yang senantiasa mengutamakan sumber daya alam yang tersedia. Temuantemuan megalitik Sulawesi Selatan menunjukan gambaran adanya kemajuan teknologi dalam mengeksploitasi sumberdaya alam yang cukup banyak tersedia di sekitar mereka. Konsep pemikiran manusia dilandasi oleh pencapaian tujuan (baik religi maupun sosial) yang mereka ciptakan sendiri untuk memenuhi kebutuhannya. Keberadaan sejumlah hasil budaya megalitik tercipta oleh adanya kehidupan yang terorganisir, dimana ada pemimpin dan masyarakat yang dipimpinnya. Mereka digerakkan oleh faktor kekuasaan (legitimasi sosial dan ekonomi) yang menciptakan hasil budaya dalam menunjang kebutuhannya. Ketika itu juga terbentuk sebuah komunitas yang kompleks dan berkembangnya sistem sosial yang kompleks.

Dalam masyarakat yang kompleks, simbol kelas-kelas sosial menjadi hal yang sangat penting dalam kebudayaan mereka seperti monumen-monumen megalitik. Penduduk tersebut membentuk suatu komunitas adat dan mendirikan kampung-kampung yang dipimpin oleh para ketua adat. Kumpulankumpulan adat tersebut semakin lama semakin berkembang ke arah yang lebih kompleks dari segi sosial, budaya, ekonomi, dan politik. Perkembangan komunitas tersebut pada 
kemudian hari, yaitu abad ke-13-14 membentuk persekutuan dan menjadi kerajaan pertama yang muncul di Sulawesi Selatan.

$* * * * *$

\section{DAFTAR PUSTAKA}

Buijs, Kees. (2009). Kuasa Berkat Dari Belantara dan Langit, Struktur dan Transformasi Agama Orang Toraja di Mamasa Sulawesi Barat. Makassar: Ininnawa.

Bulbeck, D. (2004a). Indigenous Traditions and Exogenous Influences in the Early History of Peninsular Malaysia, Dalam Southeast Asia from Prehistory to History, edited by Bellwood, P. and Glover, I. (eds.) London: Routledge Curzon.

Duli, Akin. (2012). Budaya Keranda Erong di Tana Toraja, Sulawesi, Indonesia. Tesis PhD. (tidak diterbitkan). Universiti Sains Malaysia, Pulau Pinang.

Handini, Retno. (2008). Upacara Tarik Batu di Tana Toraja dan Sumba Barat: Refleksi Status Sosial dalam Tradisi Megalitik. Dalam Kumpulan Makalah Pertemuan Ilmiah Arkeologi XI di Solo, 437-445. Jakarta: Ikatan Ahli Arkeologi Indonesia.

Harrisson, Tom. (1958). A Living Megalithic in Upland Borneo, The Sarawak Museum Journal Vol.VIII No. 12 (New Series), No. 27 (Old Series), 694-702.

Hasanuddin. (2000). Peninggalan Megalitik di Situssitus Nias Selatan: Kajian Bentuk dan Fungsi. Tesis. Fakultas Ilmu Pengetahuan Budaya Universitas Indonesia, Jakarta.

Hasanuddin. (2003). Pola Permukiman Masyarakat Toraja. Dalam buku Toraja Dulu dan Kini (Editor: Akin Duli dan Hasanuddin). Makassar: Refleksi Pustaka.

Hasanuddin. (2015). Kebudayaan Megalitik di Sulawesi Selatan dan Hubungannya dengan Asia Tenggara. Thesis Ph.D. Pulau Penang: Universiti Sains Malaysia.

Hitchner, Sarah. (2009). The Living Kelabit Landscape: Cultural Sites and Landscape Modifications in The Kelabit Highlands of Sarawak, Malaysia, The Sarawak Museum Journal 46(87): 1-76.

Koentjaraningrat. (1985). Ritus Peralihan di Indonesia. Jakarta: Balai Pustaka.

Mauss, Marcel. (1992). The Gift, Form and Functions of Exchange in Archaic Societies. Terjemahan oleh Parsudi Suparlan: Pemberian, Bentuk dan Fungsi Pertukaran di Masyarakat Kuno. Jakarta: Yayasan Obor Indonesia.
Pelras, Christian. (2006). Manusia Bugis. Terjemahan buku The Bugis oleh Abdul Rahman Abu, Hasriadi, Nurhady Sirimorok. Jakarta: Nalar.

Renfrew, Colin and Bahn, Paul. (1991). Archaeology: Theories, Method, and Practise. London: Thames and Hudson.

Rouse, Irvin. (1972). Settlement Patterns in Archaeology. Man, Settlement and Urbanism. Dalam P. J. Ucko, Ruth Tringham and G. W. Dimbledy (Eds.). 95-107. England: Duckworth.

Rousseau, J. (1990). Central Borneo: Ethnic Identity and Social Life in A Stratified Society. Oxford: Clarendon Press.

Simanjuntak, Harry Truman (Ed.). (2008). Austronesian in Sulawesi. Jakarta: Center for Prehistoric and Austronesian Studies (CPAS).

Soejono, R.P. (ed.). (1984). Sejarah Nasional Indonesia I. Jakarta: Balai Pustaka.

Yuniawati, Dwi Yani. (2006). Kubur Batu Waruga di Sub Etnis Tou'mbulu, Sulawesi Utara. Jakarta: Pusat Penelitian dan Pengembangan Arkeologi Nasional: 24.

Yuniawati, Dwi Yani. (2010). Temuan Tradisi Budaya Austronesia Akhir Protosejarah (Megalitik) di Lembah Besoa, Sulawesi Tengah. Bulletin Naditira Widya 4(2), 175191.

Yuniawati, Dwi Yani. (2014). "Laporan Penelitian Arkeologi, Potensi Peradaban Megalitik di Lembah Rampi, Kabupaten Luwu Utara, Provinsi Sulawesi Selatan” (belum terbit). 